\title{
HEPATITIS B AND C; PREVALENCE IN SOUTH PUNJAB POPULATION
}

1. Assistant Professor of Medicine, Department of Medicine,

Multan Medical and Dental College, Multan

2. Assistant Professor of Nephrology Department of Nephrology, Multan Medical and Dental College, Multan

3. Assistant Professor of Medicine Department of Medicine, Multan Medical and Dental College, Multan

Correspondence Address:

Dr. Muhammad Naveed Aslam Assistant Professor of Medicine, Department of Medicine,

Multan Medical and Dental College,

Multan

Sanasir46@yahoo.com

Article received on: 18/09/2015

Accepted for publication:

$11 / 12 / 2015$

Received after proof reading:

$13 / 01 / 2016$

\section{INTRODUCTION}

Pakistan is a developing country of 180 million people with low health and educational standards. According to the Human Development Index of the United Nations, it is ranked 146th out of 187 countries. ${ }^{1}$ Pakistan carries one of the world's highest burden of chronic hepatitis viruses (both Hepatitis B virus---HBV and Hepatitis C Virus--$\mathrm{HCV}$ )and mortality due to liver cirrhosis and heap to cellular carcinoma. ${ }^{2}$

In Pakistan, studies carried out on different segments of population have shown variable degree of prevalence in different risk groups. According to an estimate, there are about 9 million hepatitis $B$ and over 14 million hepatitis $C$ carriers all over the country. The prevalence of Hepatitis $B$ Surface Antigen (HBs Ag) and antibodies to hepatitis $\mathrm{C}$ virus (anti- $\mathrm{HCV}$ ) in young healthy Pakistani adults in recent studies carried out in different cross sections of population has ranged from
$2.56-3.53 \%$ and $2.3-5.3 \%$ respectively ${ }^{3,4,5}$ with segments of much higher prevalence as noted by Umer et al. ${ }^{6}$ However, most of these studies are based on healthy young individuals, usually as a part of pre-employment screening or blood donation which may not be a true cross-section of the whole community. This was highlighted in a review by Bosan et $\mathrm{al}^{7}$ where the lack of adequate community-based epidemiological work in Pakistan was noted.

To eradicate and control Hepatitis $B$ and $C$ virus from population as desired by $\mathrm{WHO}$, it is important to know the as actual burden of illness as possible and to determine where we actually stand as far as the prevention of the disease is concerned after 24 years of HCV discovery and the availability of effective HBV vaccination. This is important as some developing countries have achieved much on the prevention front of Hepatitis $\mathrm{B}^{8}$ and it is possible to eliminate HCV by 2030 if we in- 
crease the diagnosis and treatment 5 fold. ${ }^{9}$ So we planned a community-based cross-sectional study at Ibn-e- Siena Hospital and Research Centre to examine the prevalence of HBsAg and Anti-HCV in Southern Punjab population.

\section{Study design}

It was designed to be Cross-sectional, Observational study.

\section{Place and Duration of Study}

The study was carried out in Ibn-e-Sina Hospital and Research Centre from March 2010 to February 2014.

\section{METHODOLOGY}

A total of 26800 people from general population were included in the present study. Free vaccinationcamps were established in rural and urban union councils with the help of local politicians, in Schools, Madrassahs and Industrial units and a permanent camp was established in Ibn-e-Sina Hospital. People of all age groups andeither sex were vaccinated. Brief clinical history was recorded. For screening of $\mathrm{HBsAg}$ the architect $\mathrm{HBsAg}$ assay which is a chemi-luminescent micro practice leimmuno assays (CMIA) for quantitative determination ofhepatitis $B$ surface antigen (HBsAg) was used. This was provided by Abbott diagnostics. For HCV, ACON laboratories kit was used. The HCV one step test device (Serum/Plas$\mathrm{ma}$ ) is a rapid chromatographicimmunoassay for the qualitative detection of antibody toHepatitis $\mathrm{C}$ virus in serum or plasma. The directions ofthe manufacturers were strictly followed.

\section{RESULTS}

A total of 26800 individuals were screened, (mean: $36.47 \pm 13.81) .2090$ (7.8\%) tested positive for Anti-HCV. Among these $68.6 \%(n=1433)$ were males while $31.4 \%(n=657)$ were females. $616(2.3 \%)$ tested positive for HBsAg of which 401 (65.2\%) were male and 215 (34.8\%) were female. 75 subjects $(0.28 \%)$ were positive for both HBsAg and Anti-HCV.

The age range of the patients with seropositivity is shown in (Table-I\&II)

\begin{tabular}{|c|c|c|}
\hline Age range in Years & Numbers & Percentage \\
\hline $0-15$ & 26 & $1.82 \%$ \\
\hline $16-30$ & 265 & $18.54 \%$ \\
\hline $31-45$ & 495 & $34.54 \%$ \\
\hline $46-60$ & 503 & $35.10 \%$ \\
\hline$>60$ & 144 & $10.04 \%$ \\
\hline
\end{tabular}

Table-I. Age of the individuals with Anti-HCV Seropositivity $(n=1433)$

\begin{tabular}{|c|c|c|}
\hline Age range in Years & Numbers & Percentage \\
\hline $0-15$ & 36 & $5.84 \%$ \\
\hline $16-30$ & 145 & $23.53 \%$ \\
\hline $31-45$ & 202 & $32.79 \%$ \\
\hline $46-60$ & 165 & $26.78 \%$ \\
\hline$>60$ & 68 & $11.04 \%$ \\
\hline
\end{tabular}

Table-II. Age of the individuals with HBsAg Positivity $(n=616)$

\section{DISCUSSION}

Ours study results confirm that the menace of hepatitis continues to haunt our population. In our study, prevalence of Anti-HCV was higher than HBsAg as found in other local studies.

A study by Mirza et $\mathrm{al}^{23}$ of 1821 healthy recruits from Southern Punjab in 2005-2006 showed 5.9\% HBsAg and 2.5\% Anti-HCV seropositivity However this study only young recruits with predominance of seropositivity from MuzaffarGarh. We think this study did not reflect the load of disease in general population of Southern Punjab.

As far as prevalence of $\mathrm{HbsAg}$ and Anti-HCV in general population is concerned, our study found the prevalence of HBsAg (2.3\%) similar to that observed by another large study conducted by Khokhar et a---------2.5\% $\%^{5}$ and the National Survey conducted by PMRC ---2.5\%. ${ }^{4}$ This reflects that we have not moved much in the prevention of HBV transmission. This is worrisome as HBV is totally preventable and certain Far Eastern Countries have achieved much in this regard. ${ }^{8}$

The Prevalence of Anti-HCV (7.8\%) observed in our study was higher than observed in the National Survey ----5\% ${ }^{4}$ and other studies/meta-analysis with large population. ${ }^{3,5,6,10,22}$ But this difference 
can be explained by the fact thatfirst, ours area of study included the districts which have been reported to have the highest prevalence of Anti$\mathrm{HCV}$ in the country $>.{ }^{5}$ However, PMRC survey of the Multan District which included 1019 persons showed $7.4 \%$ prevalence which is close to that estimated by our study. Second----ours was a large community-based study as compared to other studies which are hospital-/ laboratorybased and checked the population at their doorstep and included the population across all the spectrum of age and sex so that we think it truly reflects the load of disease at least in the Southern Punjab.

\begin{tabular}{|c|c|c|c|c|}
\hline Author/Publication Year & Study Group & Number Studied & HBsAg \% & Anti-HCV \% \\
\hline Khattak MF et al ${ }^{10}$ & Blood donors & 108858 & $3.3 \%$ & $4.0 \%$ \\
\hline Zakaria Manzar et al $2003^{12}$ & Healthy Naval recruits & 963 & $3.2 \%$ & $2.2 \%$ \\
\hline Khokhar $\mathrm{N}$ et al $2004^{5}$ & $\begin{array}{l}\text { Pre-employment screening for Gulf- } \\
\text {----Islamabad }\end{array}$ & 47538 & $2.56 \%$ & $5.3 \%$ \\
\hline Farooq et al.2005 ${ }^{11}$ & Healthysoldiers & 665 & $3.0 \%$ & $3.3 \%$ \\
\hline Irfanet al. $2006^{13}$ & $\begin{array}{l}\text { Healthy adults } \\
\text { seeking recruitment }\end{array}$ & 15550 & $3.24 \%$ & $3.69 \%$ \\
\hline Nazar H et al $2008^{14}$ & Blood donors------Karachi & 11459 & $1.7 \%$ & $2.06 \%$ \\
\hline Gull-e-Atif et al $2009^{15}$ & GeneralPopulation Rawalpindi & 3800 & $2.7 \%$ & $10.4 \%$ \\
\hline Ahmed Aziz et al $2009^{16}$ & General Population swat & 3800 & $3.5 \%$ & $13.8 \%$ \\
\hline HussainShagufta et al $2010^{17}$ & $\begin{array}{l}\text { Health-care workers in Tertiary Care } \\
\text { Hospital---Islamabad }\end{array}$ & 359 & $0.5 \%$ & $1.6 \%$ \\
\hline Makhejakirpal Das et al $2010^{18}$ & $\begin{array}{l}\text { Road-side barber visitors----- } \\
\text { Karachi }\end{array}$ & 184 & Not studied & $38 \%$ \\
\hline Iqbal $\mathrm{MZ}$ et al $2011^{19}$ & $\begin{array}{l}\text { Orthopedic patients in tertiary care } \\
\text { hospital--- RYKhan }\end{array}$ & 745 & $4.8 \%$ & $16.7 \%$ \\
\hline Nafees Muhammad et al $2011^{20}$ & Jail population-----Lahore & 3062 & $3.5 \%$ & $15.3 \%$ \\
\hline Yahya et al $2011^{21}$ & Diabetic patients---Faisal Abad & 184 & ------ & $18.8 \%$ \\
\hline
\end{tabular}

\section{CONCLUSION}

We as a community need to be more vigilant as the disease burden of HBsAg is not decreasing in the general population and the Burden of Anti$\mathrm{HCV}$ is one of the highest in the world. We need to increase the prevention, diagnosis and treatment efforts by at least 05 fold to get rid of the disease in next 30 years as was noted by Hatazakis et al ${ }^{24}$ for Mediterranean countries.

\section{Copyright(C) 11 Dec, 2015.}

\section{REFERENCES}

1. United Nations Development Program. Human Development Report 2014. New York: Oxford University Press; 2014.

2. http://www.who.int/mediacentre/factsheets/fs164 \& fs204 /en/.

3. SyedAA, Rafe M.J. Donahu, Qureshi H, Vermund SH; Hepatitis B and hepatitis C in Pakistan: prevalence and risk factors:International Journal of Infectious Diseases; Volume 13, Issue 1, Pages 9-19, January 2009.

4. PMRC National Survey on Prevalence of Hepatitis B \& C in General Population of Pakistan (20072009). Pakistan Medical Research Council, Shahrah-eJamhuriat, Sector G-5/2, Islamabad.

5. Khokhar N, Gill MF, Malik GJ. General seroprevalence of hepatitis C and hepatitis B virus infections in population. J Coll Physicians Surg Pak 2004; 14: 534-6.

6. Umar M., Bushra H., Ahmad M., Khurram M, Usman S, Arif M, Adam T. et al. Hepatitis C in Pakistan: A Review of Available Data. Hepat Mon. 2010. 10(3): 205-214.

7. Bosan A, Qureshi H, Bile KM, Ahmad I, Hafiz R.A review of hepatitis viral infections in Pakistan. $J$ Pak Med Assoc. 2010 Dec;60(12):1045-58.

8. Ni YH1, Chang MH, Wu JF, Hsu HY, Chen HL, Chen DS. Minimization of hepatitis B infection by a 25-year 
universal vaccination program. J Hepatol. 2012 Oct; 57(4):730-5.

9. Wedemeyer $\mathrm{H}$, Duberg AS, ButiM, Rosenberg WM, Frankova S, G. Esmat G, et al. Strategies to manage hepatitis $C$ virus (HCV) disease burden. Journal of Viral Hepatitis, 2014, 21, (Suppl. 1), 60-89.

10. M.F. Khattak, N. Salamat, F.A Bhatti, T.Z. Qureshi. Seroprevalence of Hepatitis B, C and HIV in Blood Donors in Northern Pakistan. JPMA 52:398; 2002.

11. Farooq MA, Iqbal MA, Tariq WUZ, Hussain AB, Ghani I. Prevalence of hepatitis $B$ and $C$ in a healthy cohort. Pak J Pathol 2005; 16: 42-6.

12. Zakaria M, Ali S, Tariq GR, Nadeem M. Prevalence of anti-HCV antibodies and hepatitis $B$ surface antigen in healthy male naval recruits. Pak Armed Forces Med J 2003; 53: 3.

13. Mirza IA, Mirza SH, Irfan S, Siddiqi R, Tariq WZ, Janjua AN. Seroprevalence of Hepatitis $B$ and $C$ in young adults seekingrecruitment in armed forces. Pak Armed Forces Med J 2006; 56:192-7.

14. Nazar H, Nadia N, Shazia N, Zulfiqar A, FarhatA. Prevalence of Hepatitis B and Hepatitis C in blood donors of Karachi. Biomedica Jul - Dec 2008; 24(2):116-7.

15. AtifGul-e-, Nasir Jamal, Hayat Abbas. Seropositivity of HBsAg and Anti-HCV in Rawalpindi/lslamabad and analysis of risk factors. Ann. Pak. Inst. Med. Sci. 2009; 5(1): 242-244.

16. Ahmad A, Ahmad B, Ali A, Ahmad Y. Seroprevalence of $\mathrm{HbsAg}$ and anti-Hcv in general healthy population of swat district with frequency of different HCV genotypes. Pak J Med Sci Oct - Dec 2009; 25(5):744-8.

17. Hussain S, Patrick NA, Shams R. Hepatitis B and C prevalence and prevention awareness among health care workers in a tertiary care hospital. Int $\mathrm{J}$ Pathol 2010; 8(1):16-21.

18. Makheja KD, Abro AH, Kumar S. Sero-prevalence of hepatitis $\mathrm{C}$ antibodies in the people visiting roadside barbers. Pak J Med Sci 2010; 26(2):402-6.

19. Iqbal MZ, Azeem M, Malik MR. Hepatitis B and C prevalence in orthopedics patients. Professional Med J 2011; 18(1):69-74.

20. Nafees M, Jafferi G, Ahmed I. Jail population; a survey for HBV, HCV and HIV infections. Professional Med J 2011; 18(4):697-702.

21. Yahya K M, Iqbal K. Presence of hepatitis C virus infection among diabetic patients in Faisalabad Pakistan. J Uni Med Dent Coll2011; 2(1):13-6.

22. Waheed Y, Shafi T, Safi S.Z \&Qadril. 2009. Hepatitis C virus in Pakistan: a systematic review of prevalence, genotypes and risk factors. World J. Gastroenterol., 15: 5647-5653.

23. Mirza IA, Kazmi SMH and Janjua AN. Frequency of Hepatitis B Surface Antigen and Anti-HCV in young adults; Experience in Southern Punjab. JCPSP, Vol. 17 (2): 114-115.

24. Hatzakis A, Van Damme P, Alcorn K, Gore C, Benazzouz M, Berkane S, Buti M et al. The State of Hepatitis B and $C$ in the Mediterranean and Balkan Countries: Report from a Summit Conference.

\section{PREVIOUS RELATED STUDY}

Shabnam Naseer Awan, Shazia Nayyar, Nadeem Ashraf. OBSTETRICS AND PERINATAL OUTCOME; RISK FACTORS FOR HEPATITIS B AND C TRANSMISSION (Original) Prof Med Jour 13(4) 511-516 Oct, Nov, Dec, 2006.

Shahnaz Anwar, Sheikh Atiq-ur-Rehman, Muhammad Younis Khan. RISK FACTORS; COMPARISON IN HEPATITIS B AND C CARRIER PREGNANT WOMEN \& HEALTH PREGNANT WOMEN. (Original) Prof Med Jour 16(4) 518-525 Oct, Nov, Dec 2009.

\section{AUTHORSHIP AND CONTRIBUTION DECLARATION}

\begin{tabular}{|c|c|}
\hline Sr. \# & \multicolumn{1}{|c|}{ Author-s Full Name } \\
\hline 1 & Dr. M. Naveed Aslam \\
2 & Dr. Muhammad Nadeem \\
3 & Dr. Umar Farooq Qureshi \\
\hline
\end{tabular}

Contribution to the paper

Plomed the study, Supervised, Collected data and melysed it Supervised community comps, collected data, searched previsions wo-te done Supervised community comp, responsible for layout of the paper material and its proggresseing
Author $=\mathbf{s}$ Signature
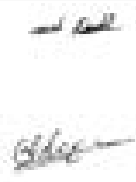